\title{
Depth-stratified soil sampling for assessing nematode communities
}

\section{Amostragem estratificada em profundidade para avaliação de comunidades de nematoides}

\author{
Giovani de Oliveira Arieira'; Débora Cristina Santiago ${ }^{2 *}$; \\ Júlio Cezar Franchini ${ }^{3}$; Maria de Fátima Guimarães ${ }^{2}$
}

\begin{abstract}
This study assessed the importance of stratified soil sampling on the detection (and therefore the distribution) of nematode communities and the differentiation of ecosystems by collecting stratified soil samples at intervals of $10 \mathrm{~cm}$ and non-stratified samples from 0 to $30 \mathrm{~cm}$ in two soil management systems (no-tillage and conventional tillage) and in a native forest fragment. The nematode frequency and prominence values were obtained after extraction by successive screening operations, sugar floatation clarification and the identification of nematodes to the genus level. The nematode communities were compared two-by-two based on Sorensen's community coefficient (CC) and the percentage similarity (PS). Relative abundances of functional guilds were subjected to a principal component analysis (PCA) and classified in dendrograms. Thirty-two edaphic nematode genera were found, and the nematode communities sampled on a non-stratified basis in the soil profile exhibited a high level of similarity because they could not be accurately characterized. Genera with low abundances were not detected. In the stratified samples, we were able to classify and group the nematodes present at different depths, mainly from 0 to $10 \mathrm{~cm}$. Stratified soil sampling allowed a more accurate characterization and greater differentiation of nematode communities, identifying taxa that occurred at lower abundance levels, irrespective of frequency.

Key words: Bioindicators. Free-living nematodes. Nematofauna. Similarity. Vertical distribution.
\end{abstract}

\section{Resumo}

Com o objetivo de avaliar a importância da amostragem estratificada de solos na detecção (assim como na distribuição) de comunidades de nematoides e na diferenciação de ecossistemas, amostras de solo estratificadas em intervalos de $10 \mathrm{~cm}$ e não estratificadas de 0 a $30 \mathrm{~cm}$ foram coletadas em dois sistemas de prepare do solo (plantio direto e preparo convencional), e em um fragmento de floresta nativa. Após extração por peneiramento sucessivo, clarificação por flotação em sacarose e identificação dos nematoides até nível de gênero, a frequência e proeminência dos nematoides foram obtidas. As comunidades de nematoides foram comparadas duas a duas, baseadas no Coeficiente de comunidade de Sorensen e na Similaridade percentual (PS). Abundâncias relativas das guildas funcionais foram submetidas à Análise de componentes principais (PCA) e classificadas em dendrogramas. Trinta e dois gêneros de nematoides edáficos foram encontrados e as comunidades de nematoides amostradas de forma não estratificada no perfil do solo apresentaram um maior nível de similaridade entre si, pois não foram corretamente caracterizadas e os gêneros com baixa abundância não foram detectados. Nas amostras estratificadas, foi possível classificar e agrupar os nematoides presentes em diferentes profundidades, principalmente

\footnotetext{
${ }^{1}$ Discente do Curso de Doutorado do Programa de Pós-Graduação em Agronomia, Dept ${ }^{o}$, Universidade Estadual de Londrina, UEL, Londrina, PR, Brasil. E-mail: giovaniarieira@yahoo.com.br;

2 Prof ${ }^{\text {as }}$, Dr ${ }^{\text {as }}$, Dept ${ }^{\circ}$ de Agronomia, UEL, Londrina, PR, Brasil. E-mail: santiago@uel.br; mfatima@uel.br

${ }^{3}$ Pesquisador, Empresa Brasileira de Pesquisa Agropecuária, EMBRAPA Soja, Londrina, PR, Brasil. E-mail: franchin@cnpso. embrapa.br

* Author for correspondence
} 
de 0 a $10 \mathrm{~cm}$. A amostragem estratificada do solo permitiu uma caracterização mais precisa e uma maior diferenciação das comunidades de nematoides, pela identificação de taxa que ocorrem em baixa abundância, independente da frequência.

Palavras-chave: Bioindicadores. Distribuição vertical. Nematofauna. Nematoides de vida livre. Similaridade.

\section{Introduction}

Bioindicators can measure soil quality (ARAÚJO; MONTEIRO, 2007), and nematodes have been used for this purpose because they occupy key positions in the soil food web (NEHER, 2001). Furthermore, they respond rapidly to changes in the environment (BONGERS; FERRIS, 1999), are abundant in the soil (FRECKMAN; ETTEMA, 1993), are widely distributed (CURRY, 1994) and extend over various trophic groups (YEATES et al., 1993). They also present facilities in sample and extraction because of their abundance and small size compared with other groups of soil organisms (NEHER, 2001).

In studies conducted in tropical regions, nematodes have proved to be effective as a means of verifying the effects of the most diverse management systems on soil quality (MATTOS et al., 2006; KORENKO; SCHIMIDT, 2006; YEATES, 2007; CARES; HUANG, 2008; RODRIGUES et al., 2011; SANTIAGO et al., 2012). However, defining an appropriate method of collecting samples is fundamental for obtaining representative samples, especially because the reliability of an assessment based on samples depends upon the efficiency of the sampling pattern and design (GOULART, 2007). Furthermore, the interpretation of impacts on the nematode community must take account of both their horizontal and vertical distributions in the soil (MENG et al., 2006).

Horizontal nematode distribution has already been well elucidated. Nematodes typically occur in aggregates, especially plant-parasitic nematodes (GOULART, 2007) because they are affected by root distribution, soil type and moisture content, as well as other physical and biological factors (FREITAS et al., 2001). In contrast, the vertical distribution varies considerably and, in agroecosystems, nematodes tend to be concentrated in the upper $20 \mathrm{~cm}$ of soil (NORTON; NIBLACK, 1991; BONGERS, 1999). Samples used to be taken at depths of $0-20 \mathrm{~cm}$ or 0-30 cm (GOULART, 2007), and few studies have been conducted based on a stratified soil sampling method at different soil depths (TOMAZINI et al., 2008; RODRIGUES et al., 2011).

It is therefore essential to understand the impact of the soil sampling method on the detection, and therefore diversity, of the organisms assessed, and especially to understand the stratification of the samples. Patterns of diversity consist basically of $\alpha$ diversity (occurring in the in situ organisms community), $\beta$ diversity (between two communities) and $\gamma$ diversity (on a regional level), with the first two related to the sampling method (GOULART, 2007) and the last affected by other wider factors such as climate and plant cover (SMITH; SMITH, 2008). Although this type of study is rarely conducted in edaphic ecosystems, the influence of stratification on the assessment of nematode communities has been confirmed in studies of marine sediments (STEYAERT et al., 2003).

Therefore, the aim of this study was to confirm the implications of stratified soil sampling in the characterization of ecosystems and how it affects the differentiation between nematode communities.

\section{Material and Methods}

\section{Experimental site}

The study was conducted in the experimental area of the National Soybean Research Center (Embrapa - Soja) in Londrina, Paraná, Brazil ( $23^{\circ} 11^{\prime} \mathrm{S}, 51^{\circ} 11^{\prime} \mathrm{W}, 620 \mathrm{~m}$ altitude). The climate in the region is classified as $C f a$ (humid mesothermal) 
in the Köppen-Geiger system, and the soil is classified as an Oxisol (Eutroferric Red Latosol in the Brazilian classification, or Rhodic Eutrudox in the USA classification) with $710 \mathrm{~g}$ clay $\mathrm{kg}^{-1}$ soil, 82 $\mathrm{g}$ silt $\mathrm{kg}^{-1}$ soil, and $208 \mathrm{~g}$ sand $\mathrm{kg}^{-1}$ soil. The native vegetation is the Atlantic forest, classified as a semideciduous seasonal forest (IBGE, 1992).

The experimental sites were set up 22 years ago, and two farming systems and an area of native forest (FO) adjacent to the experimental area were assessed. The agricultural plots were $50 \mathrm{~m} \times 8 \mathrm{~m}$, with a randomized block experimental design and four replications as follows: conventional tillage (CT) with a $20-\mathrm{cm}$ disk plow and leveling harrow and no-tillage (NT), which disturbed the soil only on the sowing line. Both plots were under a crop rotation of soybean (Glycine max), wheat (Triticum aestivum), maize (Zea mays), white lupine (Lupinus albus), forage radish (Raphanus sativus) and black oats (Avena strigosa).

\section{Sampling, extraction and identification of nematodes}

Samples were collected immediately after the soybean harvest in March, 2011 based on a modified version of the method proposed by Anderson and Ingram (1993), collecting three soil subsamples and forming a composite sample of approximately 1500 $\mathrm{cm}^{3}$ from each experimental plot. The same method was used for collecting samples from random points at least $50 \mathrm{~m}$ apart in the forest fragment.

To verify the influence of the sampling method on assessments of the nematode communities, stratified samples were collected at depths of 0-10 $\mathrm{cm}, 10-20 \mathrm{~cm}$ and $20-30 \mathrm{~cm}$ in the soil profile (total sampling profile depth $-30 \mathrm{~cm}$ ). Samples were packed in plastic bags and kept at $4{ }^{\circ} \mathrm{C}$ until processed.

To extract the nematodes, $300 \mathrm{~cm}^{3}$ of soil were placed in suspension in $2 \mathrm{~L}$ of water and homogenized, then sieved through successive screens of $0.84,0.075$ and $0.025 \mathrm{~mm}$. Next, the suspension containing the nematodes was clarified by sugar centrifugal floatation (JENKINS, 1964) and kept in formalin ( $4 \%$ formaldehyde). The total number of nematodes was estimated on a counting slide, and 200 random individuals were identified to genus level under an optical microscope, in accordance with Goseco et al. (1974a, 1974b), Bongers (1987), Fortuner et al. (1988) and De Ley and Blaxter (2002).

\section{Assessment of nematode communities and data analysis}

For each genus, we obtained the frequency ( $f a=$ $P a / P$, where $P a$ represents the number of samples in which the taxon occurred and $P$ the total number of samples) and the prominence value ( $V p=A a \mathrm{x}$ $\sqrt{ } f a$, where $A a$ represents the absolute abundance of a given taxon and $f a$ the absolute frequency of this taxon), in accordance with Norton (1978) and Goulart (2007). After grouping the genera into functional guilds (according to the classification in FERRIS et al., 2001), we obtained their relative abundance values (percentage weighting in the community).

To verify similarities between ecosystems, the communities at each level were compared two-bytwo based on Sorensen's community coefficient (CC) and the percentage similarity (PS). Sorensen's community coefficient is obtained using the formula $\mathrm{CC}=2 c /\left(s_{1}+s_{2}\right)$, where $c$ is the number of species common to both communities and $s_{1}$ and $s_{2}$ are the total number of species in communities 1 and 2 . The percentage similarity (PS) is the sum of the lowest relative abundances of each genus common to both communities (SMITH; SMITH, 1998).

For each sampling depth, the relative abundances of the functional guilds were subjected to a multivariate statistical analysis (principal component analysis) and a hierarchical classification (dendrograms), as recommended by Valentin (2000), with loadings higher than 0.30 considered significant (HAIR et al., 1998). 


\section{Results}

Irrespective of the sampling method, 32 edaphic nematode genera were found, but the distribution of these genera varied according to soil depth and management system (Tables 1 and 2). In terms of frequency, seven genera (Eudorylaimus, Hoplolaimus, Ironus, Monhystera, Nygolaimus, Pratylenchus and Psilenchus) were not found when the sampling was non-stratified in the soil profile, although they were observed in at least one stratified sample.

Table 1. Soil nematode genera frequency $(f a)$ in communities characterized by the two samples method (stratified soil samples at intervals of $10 \mathrm{~cm}$ and non-stratified samples from 0 to $30 \mathrm{~cm}$ ).

\begin{tabular}{|c|c|c|c|c|c|c|c|c|c|c|c|c|}
\hline \multirow{2}{*}{ Genera } & \multicolumn{3}{|c|}{$0-10 \mathrm{~cm}$} & \multicolumn{3}{|c|}{$10-20 \mathrm{~cm}$} & \multicolumn{3}{|c|}{$20-30 \mathrm{~cm}$} & \multicolumn{3}{|c|}{$0-30 \mathrm{~cm}$} \\
\hline & FO & $\mathrm{CT}$ & NT & FO & $\mathrm{CT}$ & NT & FO & CT & NT & $\mathrm{FO}$ & $\mathrm{CT}$ & NT \\
\hline Acrobeles & 1 & 1 & 0.75 & 0.75 & 1 & 1 & 1 & 1 & 0.75 & 1 & 1 & 1 \\
\hline Acrobeloides & 0.75 & 0 & 1 & 1 & 0.75 & 1 & 0.75 & 1 & 1 & 1 & 1 & 1 \\
\hline Alaimus & 0 & 0 & 1 & 0.75 & 0.75 & 0.75 & 1 & 0 & 0.5 & 0.75 & 0.5 & 0.75 \\
\hline Aphelenchoides & 1 & 0 & 1 & 1 & 0.75 & 0.5 & 0.25 & 1 & 1 & 1 & 0.75 & 1 \\
\hline Aphelenchus & 1 & 1 & 1 & 0.75 & 0.75 & 0 & 0.5 & 0.25 & 0 & 0.75 & 1 & 1 \\
\hline Cephalobus & 1 & 0 & 0.75 & 1 & 1 & 1 & 1 & 1 & 1 & 1 & 1 & 0.75 \\
\hline Chiloplacus & 0 & 0 & 0 & 0.5 & 1 & 0 & 0.75 & 1 & 0.5 & 0.5 & 1 & 0.75 \\
\hline Discocrinemella & 1 & 0 & 0 & 1 & 0 & 0 & 1 & 0 & 0 & 1 & 0 & 0 \\
\hline Dorylaimellus & 0.75 & 0 & 0 & 1 & 0.5 & 0.25 & 0 & 0.25 & 0 & 0.75 & 0.5 & 0.75 \\
\hline Eudorylaimus & 1 & 0 & 0 & 0.25 & 0.25 & 0 & 0 & 0 & 0.75 & 0 & 0 & 0 \\
\hline Helicotylenchus & 1 & 1 & 1 & 1 & 1 & 1 & 1 & 1 & 1 & 1 & 1 & 1 \\
\hline Hoplolaimus & 0 & 0 & 0 & 0 & 0 & 0.75 & 0 & 0 & 0 & 0 & 0 & 0 \\
\hline Ironus & 1 & 0 & 1 & 0.75 & 0 & 0 & 0.25 & 0 & 0 & 0 & 0 & 0 \\
\hline Labronema & 1 & 1 & 1 & 0 & 0.5 & 0 & 0 & 0.75 & 0 & 0.5 & 0.5 & 0.75 \\
\hline Mesocriconema & 1 & 0 & 0 & 1 & 0 & 0 & 1 & 0 & 0 & 1 & 0 & 0.25 \\
\hline Mesodorylaimus & 0 & 1 & 0 & 0 & 0 & 0 & 0 & 0 & 0 & 0 & 0.5 & 0 \\
\hline Mesorhabditis & 0.75 & 0.75 & 0.75 & 0 & 1 & 1 & 0.5 & 1 & 1 & 0.5 & 1 & 1 \\
\hline Monhystera & 0 & 0 & 0 & 0 & 0.75 & 0.75 & 0 & 0 & 0 & 0 & 0 & 0 \\
\hline Mononchus & 0 & 0 & 0 & 0 & 0.75 & 0 & 0 & 0 & 1 & 0 & 0 & 0.5 \\
\hline Mychonchus & 1 & 0 & 0 & 1 & 0 & 0 & 0 & 0 & 0 & 0.5 & 0 & 0 \\
\hline Nygolaimus & 0 & 0 & 0 & 0.25 & 0.75 & 0 & 0.5 & 1 & 0 & 0 & 0 & 0 \\
\hline Panagrolaimus & 1 & 1 & 1 & 1 & 1 & 1 & 0 & 1 & 1 & 0.75 & 1 & 1 \\
\hline Plectus & 0 & 0 & 0 & 0.75 & 1 & 1 & 1 & 0 & 0 & 0.75 & 0.5 & 0.5 \\
\hline Prionchulus & 1 & 0 & 0 & 0 & 0 & 0 & 0 & 1 & 1 & 0.5 & 0.25 & 0.5 \\
\hline Prismatolaimus & 0 & 1 & 1 & 1 & 0.75 & 0 & 1 & 1 & 1 & 0.75 & 0.75 & 0.75 \\
\hline Prodorylaimus & 0.5 & 1 & 1 & 0.75 & 0.75 & 0 & 0 & 0 & 0 & 0.5 & 0.25 & 0.5 \\
\hline Psilenchus & 1 & 0 & 0 & 0 & 0.75 & 0 & 0 & 0 & 0.5 & 0 & 0 & 0 \\
\hline Rhabditis & 1 & 0.75 & 1 & 1 & 1 & 1 & 0 & 0 & 0 & 0.75 & 1 & 0.75 \\
\hline Rotylenchulus & 0 & 0.75 & 0.75 & 0.75 & 1 & 0 & 1 & 1 & 1 & 1 & 1 & 1 \\
\hline Scutellonema & 1 & 0 & 1 & 0.25 & 0.25 & 1 & 1 & 0 & 0.75 & 0.75 & 0.25 & 1 \\
\hline Tylenchus & 0.75 & 0 & 1 & 1 & 1 & 1 & 0.5 & 1 & 1 & 1 & 0.75 & 0.5 \\
\hline
\end{tabular}

NT: No-tillage, CT: Conventional tillage, FO: Forest fragment. 
Table 2. Soil nematode proeminence value $(f a)$ in communities characterized by the two samples method (stratified soil samples at intervals of $10 \mathrm{~cm}$ and non-stratified samples from 0 to $30 \mathrm{~cm}$ ).

\begin{tabular}{|c|c|c|c|c|c|c|c|c|c|c|c|c|}
\hline \multirow{2}{*}{ Genera } & \multicolumn{3}{|c|}{$0-10 \mathrm{~cm}$} & \multicolumn{3}{|c|}{$10-20 \mathrm{~cm}$} & \multicolumn{3}{|c|}{$20-30 \mathrm{~cm}$} & \multicolumn{3}{|c|}{$0-30 \mathrm{~cm}$} \\
\hline & FO & CT & NT & FO & CT & NT & FO & CT & NT & FO & CT & NT \\
\hline Acrobeles & 12.38 & 4.25 & 1.52 & 0.76 & 1.38 & 2.13 & 4.88 & 1.25 & 0.76 & 8.13 & 5.00 & 2.50 \\
\hline Acrobeloides & 1.41 & - & 1.88 & 18.25 & 3.25 & 2.38 & 3.36 & 11.75 & 14.50 & 8.88 & 6.63 & 8.50 \\
\hline Alaimus & - & - & 1.50 & 1.62 & 2.81 & 0.76 & 1.50 & - & 0.53 & 0.76 & 0.62 & 1.19 \\
\hline Aphelenchoides & 1.88 & - & 5.63 & 4.13 & 3.25 & 1.24 & 0.13 & 2.50 & 6.13 & 2.13 & 0.76 & 3.50 \\
\hline Aphelenchus & 4.13 & 5.38 & 16.25 & 0.54 & - & - & 0.71 & 0.13 & - & 1.19 & 1.88 & 8.25 \\
\hline Cephalobus & 2.13 & - & 1.41 & 10.13 & 6.38 & 7.50 & 12.63 & 4.75 & 4.25 & 7.88 & 3.13 & 3.03 \\
\hline Chiloplacus & - & - & - & 0.18 & - & - & 2.92 & 20.13 & 2.74 & 0.44 & 8.13 & 2.17 \\
\hline Discocrinemella & 0.63 & - & - & 22.88 & - & - & 20.38 & - & - & 15.64 & - & - \\
\hline Dorylaimellus & 1.41 & - & - & 4.25 & 0.18 & 0.13 & - & 0.31 & - & 1.41 & 0.18 & 1.30 \\
\hline Eudorylaimus & 9.25 & - & - & 0.13 & - & - & - & - & 1.41 & - & - & - \\
\hline Helicotylenchus & 1.38 & - & 3.50 & 4.88 & 38.38 & 40.38 & 6.75 & 11.38 & 12.13 & 7.88 & 32.38 & 29.13 \\
\hline Hoplolaimus & - & - & - & - & - & - & - & - & - & - & - & - \\
\hline Ironus & 22.13 & - & - & 0.43 & - & - & 0.06 & - & - & - & - & - \\
\hline Labronema & - & 2.63 & - & - & - & - & - & 1.30 & - & 0.71 & 0.44 & 0.65 \\
\hline Mesocriconema & 2.75 & - & - & 13.13 & - & - & 15.88 & - & - & 18.88 & - & 0.13 \\
\hline Mesodorylaimus & - & 1.00 & - & - & - & - & - & - & - & - & 0.27 & - \\
\hline Mesorhabditis & 0.65 & 0.65 & 0.65 & - & 9.00 & 5.88 & 0.53 & 12.38 & 6.38 & 0.27 & 6.38 & 6.13 \\
\hline Monhystera & - & - & - & - & 0.87 & 2.60 & - & - & - & - & - & - \\
\hline Mononchus & - & - & - & - & - & - & - & - & 2.75 & - & - & 0.27 \\
\hline Mychonchus & 1.50 & - & - & 2.13 & - & - & - & - & - & 0.88 & - & - \\
\hline Nygolaimus & - & - & - & 0.06 & - & - & 0.35 & 2.00 & - & - & - & - \\
\hline Panagrolaimus & 4.75 & 2.00 & 0.88 & 3.00 & 9.38 & 8.13 & - & 7.88 & 12.88 & 1.73 & 9.88 & 10.38 \\
\hline Plectus & - & - & - & 1.30 & 5.00 & 6.63 & 10.13 & - & - & 1.95 & 0.62 & 0.44 \\
\hline Prionchulus & 0.88 & - & - & - & - & - & - & 2.25 & 7.00 & 0.18 & 0.06 & 0.80 \\
\hline Prismatolaimus & - & 5.88 & 3.25 & 3.50 & - & - & 7.00 & 7.00 & 3.00 & 1.41 & 2.27 & 1.52 \\
\hline Prodorylaimus & 0.35 & 2.88 & 5.50 & 0.54 & - & - & - & - & - & 0.18 & 0.13 & 0.62 \\
\hline Psilenchus & 1.75 & - & - & - & - & - & - & - & 0.80 & - & - & - \\
\hline Rhabditis & 2.00 & 1.30 & 3.00 & 3.00 & 13.13 & 6.38 & - & - & - & 0.97 & 6.13 & 1.84 \\
\hline Rotylenchulus & - & 21.76 & 1.84 & 1.08 & - & - & 4.75 & 10.13 & 11.88 & 2.13 & 10.88 & 7.00 \\
\hline Scutellonema & 2.00 & - & 11.13 & 0.13 & 0.88 & 0.38 & 4.38 & 0.00 & 1.41 & 1.52 & 0.06 & 6.50 \\
\hline Tylenchus & 0.97 & - & 2.00 & 2.63 & 2.13 & 1.38 & 1.33 & 4.25 & 6.00 & 5.63 & 2.27 & 0.97 \\
\hline
\end{tabular}

NT: No-tillage, CT: Conventional tillage, FO: Forest fragment.

In contrast, the frequency of Acrobeles, Acrobeloides, Helicotylenchus and Rotylenchulus was $100 \%$ under all management systems when non-stratified sampling was used, but only Helicotylenchus exhibited the same tendency in the stratified samples. It is worth noting that although Acrobeles and Acrobeloides were observed in at least $75 \%$ of stratified samples, Rotylenchulus was not found in some areas and at some depths.
It was also observed that stratified sampling produced more variable results in all ecosystems, as evidenced by the significant difference between the maximum and minimum numbers of genera (Figure 1). In addition, the cumulative number of genera was higher in non-stratified sampling, although this was not reflected in the average number of genera. 
Figure 1. Soil nematode diversity in communities characterized by the two samples method (stratified soil samples at intervals of $10 \mathrm{~cm}$ and non-stratified samples from 0 to $30 \mathrm{~cm}$ ).

A

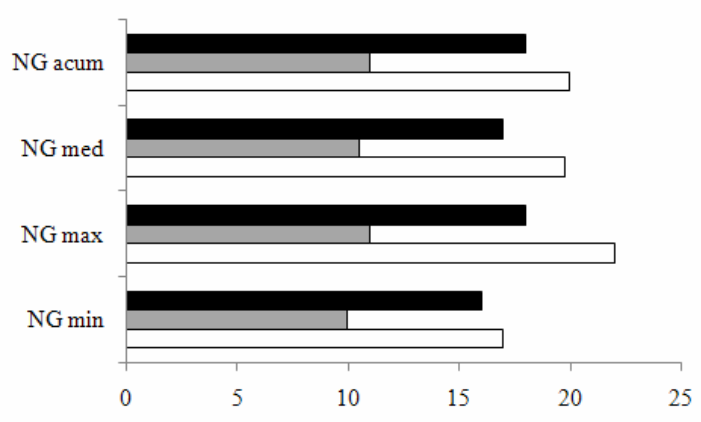

C

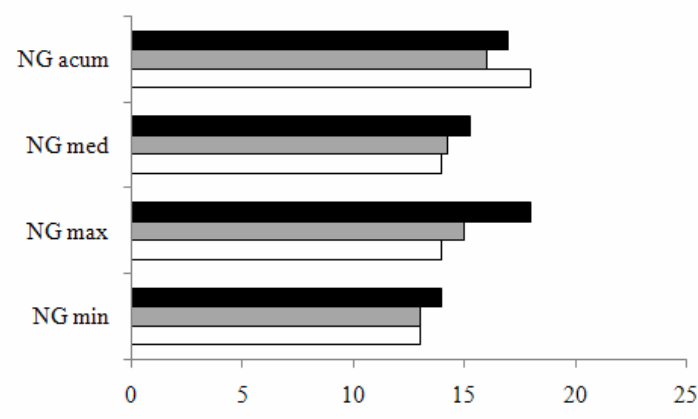

B

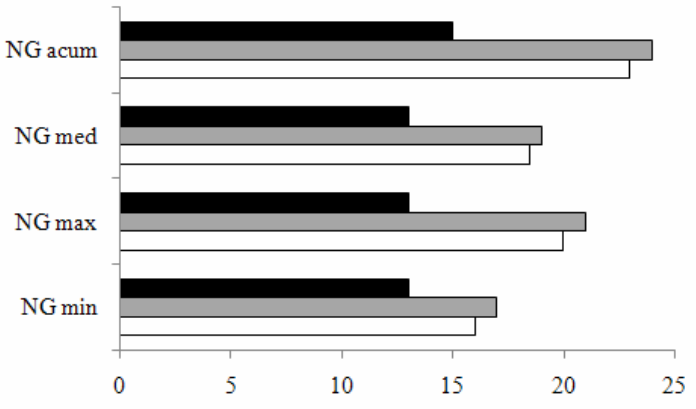

D

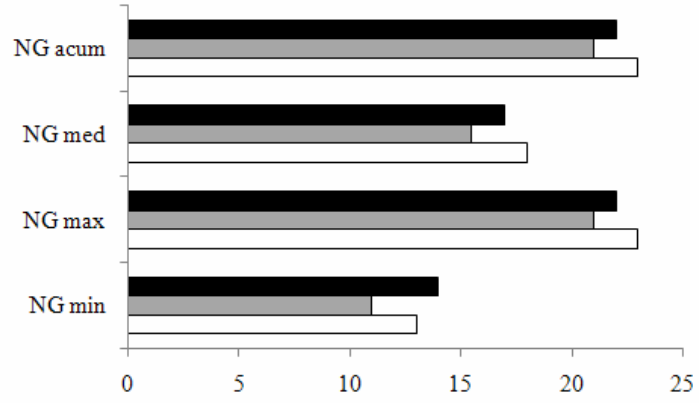

-CT 口NT $\square$ FO

A: $0-10 \mathrm{~cm}, \mathrm{~B}: 10-20 \mathrm{~cm}, \mathrm{C}: 20-30 \mathrm{~cm}, \mathrm{D}: 0-30 \mathrm{~cm}, \mathrm{NG}$ : Number of genus, Acum: Accumulated, Med: Medium, max: Maximum, min: Minimum, NT: No-tillage, CT: Conventional tillage, FO: Forest fragment.

Assessing these biological attributes from one ecosystem to another, we noted that the nonstratified samples exhibited greater homogeneity, making it more difficult to observe differences between the management systems. In contrast, when the same ecosystems were assessed using stratified soil sampling, there were obvious differences at depths of 0-10 $\mathrm{cm}$ and 10-20 cm.

In terms of the occurrence of genera in communities, Figure 2A shows that when stratified sampling was used, the ecosystems are clearly differentiated down to a depth of $20 \mathrm{~cm}$. The stratified soil samples showed that the similarity between the soil management systems (approximately 0.75) was significant, in contrast to a comparison between the forest soil and conventional tillage (results always below 0.50). However, at depths of 20-30 cm, all similarity values were the same and always below 0.75. When non-stratified soil sampling was used, no differences were observed between ecosystems, and there were high similarities between all communities (values higher than 0.95).

When the weightings of the genera were taken into account (Figure 2B), there was no difference between the trends exhibited in the stratified and non-stratified samples, with greater similarity between the management systems. 
Figure 2. Similarity between soil nematode communities characterized by the two samples method (stratified soil samples at intervals of $10 \mathrm{~cm}$ and non-stratified samples from 0 to $30 \mathrm{~cm}$ ).

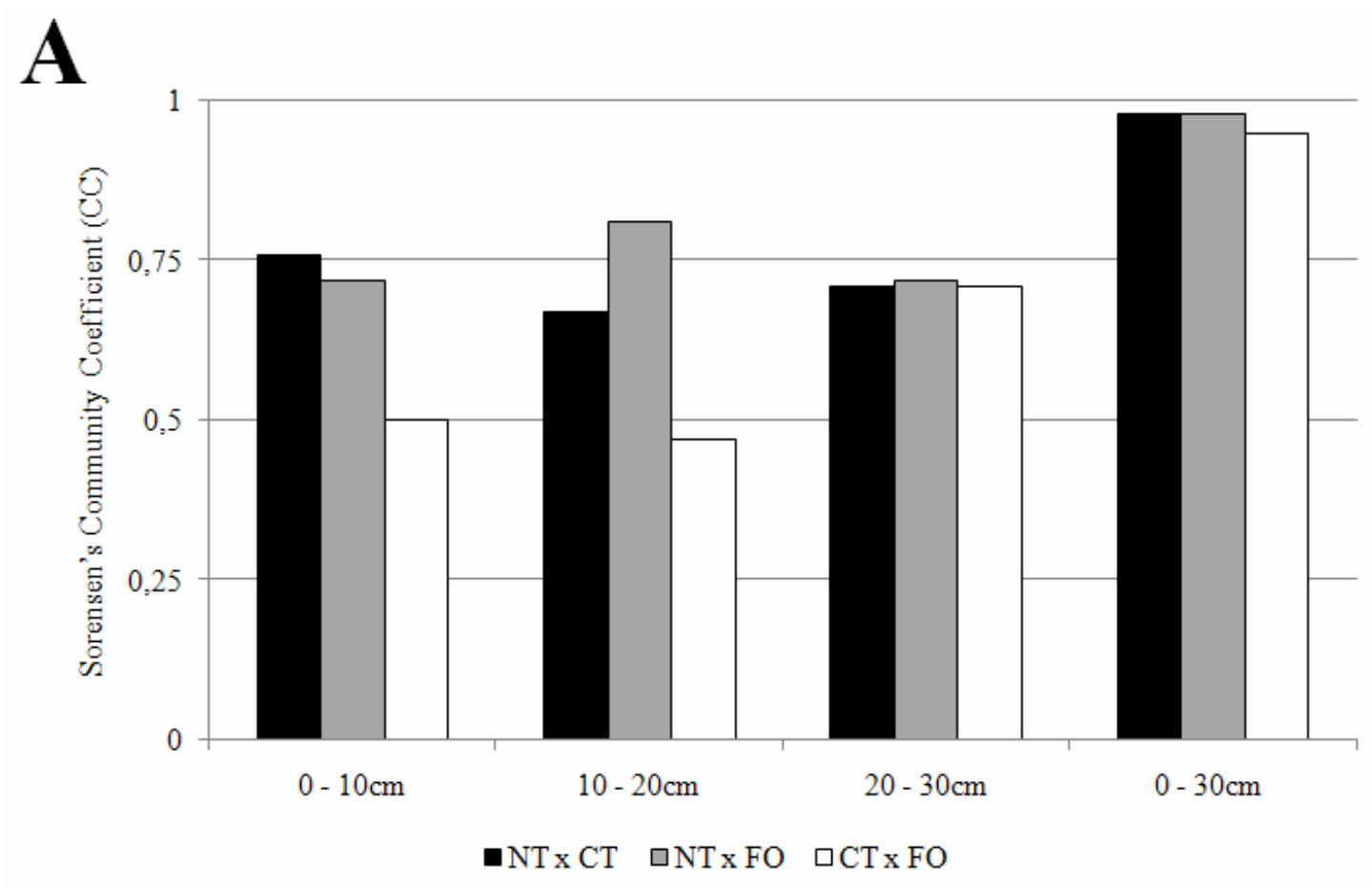

B

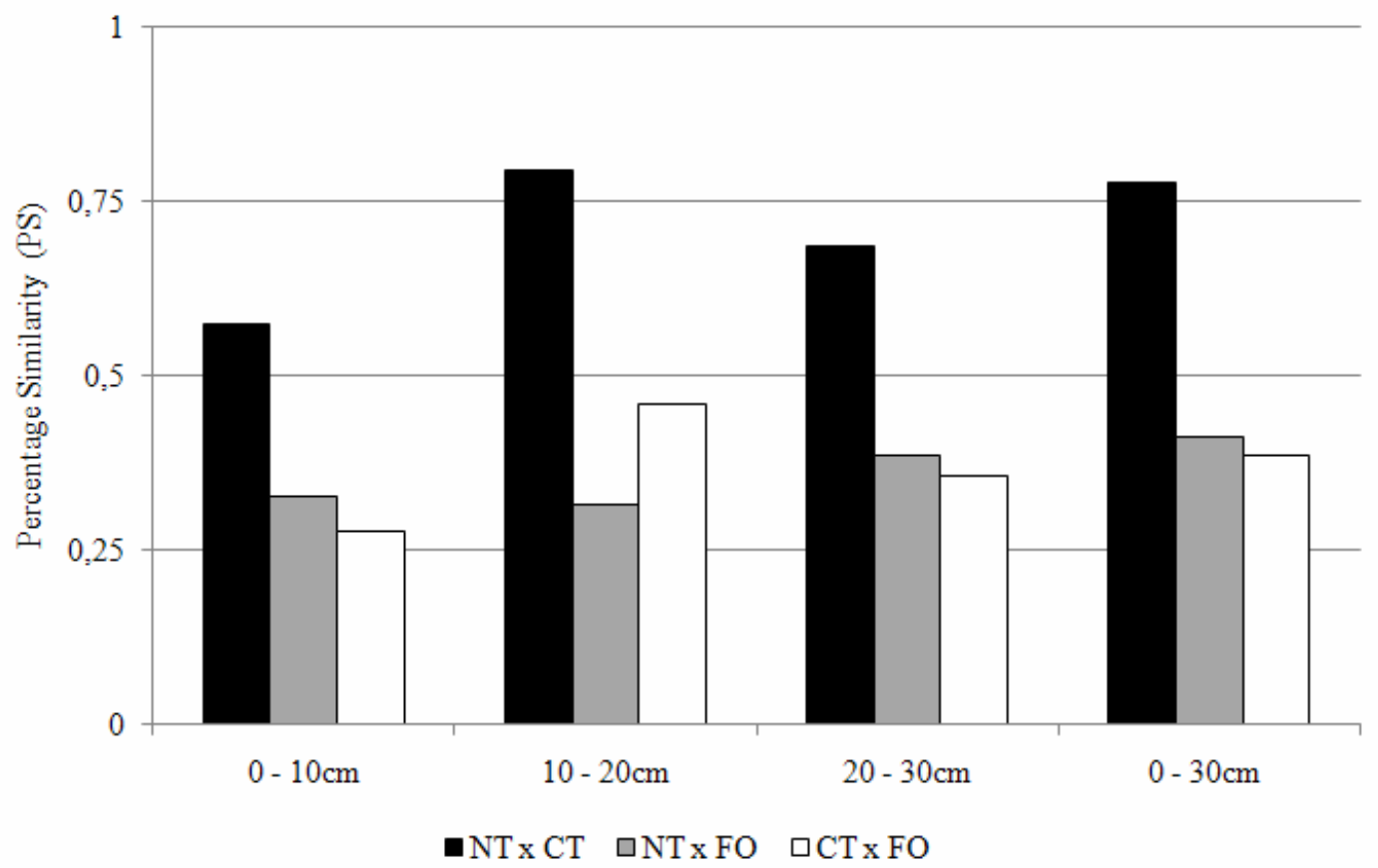

A: Sorensen's community coefficient (CC), B: Percentage similarity (PS), NT: No-tillage, CT: Conventional tillage, FO: Forest fragment. 
In terms of functional guild distribution carnivorous nematodes. There were five distinct (Figures 3 and 4), a principal component analysis groups, with a clear distinction between samples explains $64.99 \%$ of the data variability, with axis in the $0-10 \mathrm{~cm}$ layer and those taken in the other 1 accounting for $36.94 \%$ and axis 2 accounting for $28.05 \%$. Non-stratified sampling showed a positive relationship between plant-parasitic and bacterialfeeding nematodes (low c-p values), and a negative relationship between bacterial-feeding (c-p 3) and layers, as well as a tendency toward classification on the basis of depth (methodology). Non-stratified samples and samples in the 20-30 cm layer showed a tendency toward grouping, according to the management system used.

Figure 3. Principal Component Analysis (PCA) with nematode functional guilds (FERRIS et al., 2001) of communities characterized by the two samples method (stratified soil samples at intervals of $10 \mathrm{~cm}$ and non-stratified samples from 0 to $30 \mathrm{~cm}$ ).

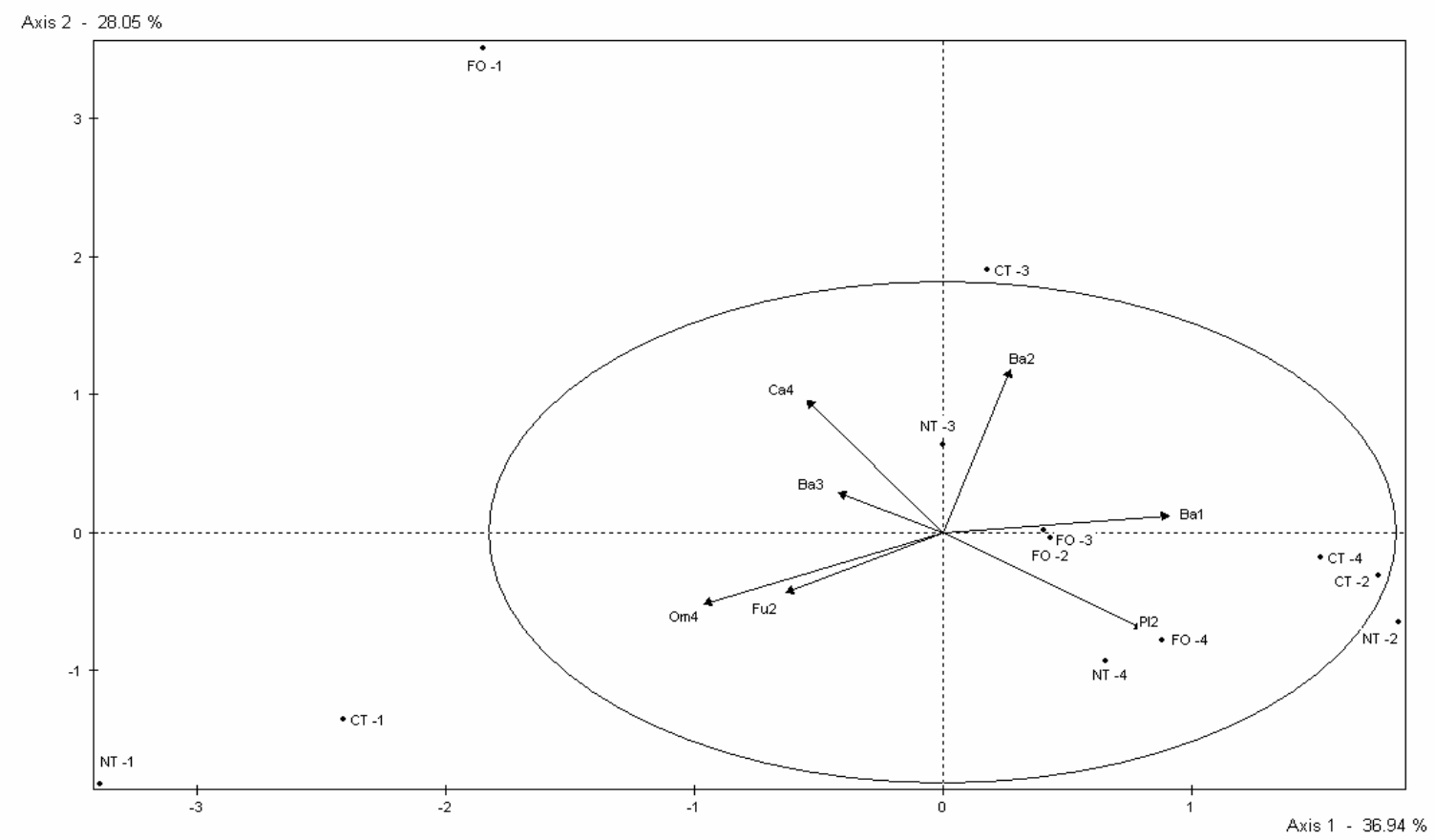

NT: No-tillage, CT: Conventional tillage, FO: Forest fragment. 
Figure 4. Cluster Analysis with nematode functional guilds (FERRIS et al., 2001) of communities characterized by the two samples method (stratified soil samples at intervals of $10 \mathrm{~cm}$ and non-stratified samples from 0 to $30 \mathrm{~cm}$ ).

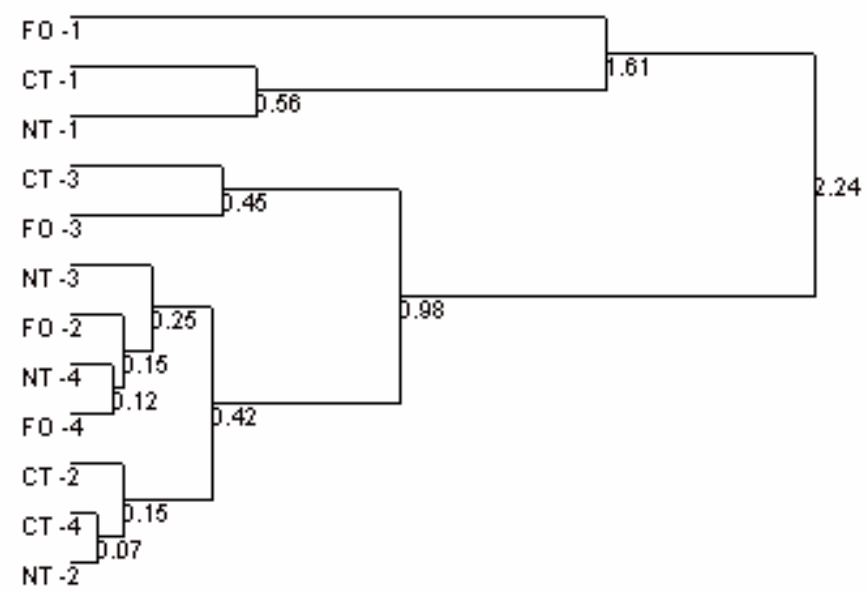

NT: No-tillage, CT: Conventional tillage, FO: Forest fragment, 1: $0-10$ $\mathrm{cm}, 2: 10-20 \mathrm{~cm}, 3: 20-30 \mathrm{~cm}, 4: 0-30 \mathrm{~cm}$.

\section{Discussion}

The gradual drop in the number of nematodes as the soil depth increases indicates stratified biological activity, according to soil type (YEATES, 1980), time of the year at which sampling was conducted (LIANG et al., 1999) and anthropogenic disturbances (YEATES; KING, 1997). However, not all nematodes are distributed in the same way throughout the soil profile, implying that results can be affected by the sampling method, depending on which key groups are to be identified and the objectives of the study.

When a single sample is taken from the soil profile, the nematodes are rendered homogeneous, although the nematode distribution in the soil profile is known to be extremely variable. Meng et al. (2006) observed that over $70 \%$ of nematodes were concentrated in the top $20 \mathrm{~cm}$ of soil, and Hou et al. (2010) reported a predominance of approximately $60 \%$ in the top $15 \mathrm{~cm}$. However, we should bear in mind that the taxonomic groups occurring in these areas vary considerably at specific depths and according to the soil management systems used.

The detection of high frequency, abundant nematodes, such as Helicotylenchus, remained unaffected by the sampling method in all the areas assessed, as well as for the Criconematidae family in the forest area. Goulart and Ferraz (2003) observed that these nematode groups are abundant, but vary according to the type of soil use, reporting that Helicotylenchus spp. were more abundant under maize and guava, whereas Cerrado areas showed high abundances of Discocriconemella spp. Furthermore, high populations of Helicotylenchus spp. have been reported in other studies conducted in Brazilian agroecosystems (RODRIGUES et al., 2011) and even in nematode communities under native vegetation (SANTIAGO et al., 2012). The occurrence of nematodes from the Criconematidae family exclusively in areas of native vegetation has already been reported by Tomazini et al. (2008), who observed that Discocrinemella was the most abundant genus down to a depth of $30 \mathrm{~cm}$.

On the other hand, the detection of lowabundance genera was very significantly affected by the sampling method, and in some cases, these genera remained undetected when non-stratified sampling was used, even when their frequencies were high at specific depths. Seven nematode genera not found in non-stratified samples at depths of 0-30 
$\mathrm{cm}$ were detected by stratified sampling because these nematodes are restricted to certain depths, and even where frequent, their abundance is very low.

Nematodes of the genera Ironus, Eudorylaimus and Psilenchus were present at a constant frequency in more than one treatment. Because omnivorous nematodes of the Dorylaimidae family can be restricted to certain soil depths (RODRIGUES et al., 2011) and populations are usually low, especially in agricultural areas (NEHER; CAMPBELL, 1994; GOULART; FERRAZ, 2003; TOMAZINI et al., 2008), the sampling method can significantly affect the results obtained. Because they are associated with anthropogenic activity and ongoing farming practices (GOMES et al., 2003), they form important groups in differentiating between the ecological processes that occur in agroecosystems and native ecosystems.

In this respect, note that the stratified soil sampling does not affect the detection of rare taxonomic groups because low-frequency nematodes have been found irrespective of the sampling method used. For these rare nematodes, the sampling method does not significantly affect the results, and for assessments intended to monitor specific groups in the community, non-stratified sampling can be used with no loss of relevant information.

The importance of stratified sampling for detecting rare nematode groups, especially in tropical regions, is linked to the fact that differences between ecosystems often go unnoticed, even when there are fairly significant differences in the degree of ecological disturbance (BLOEMERS et al., 1997). In Brazil, Mattos et al. (2006) reported that diversity indices can prove fairly ineffective for differentiating agricultural systems, whereas using the number and richness of genera can be much more effective.

Non-stratified sampling can result in very high similarity values, making it difficult to differentiate natural and anthropogenic systems, whereas stratified sampling allows communities to be more clearly differentiated and is therefore more appropriate for agroecosystems in which different management practices are used, resulting in the dominance of some genera at certain soil depths (LIANG et al., 2005).

The loss of sensitivity in the detection of some nematode genera is shown by the drop in the maximum and minimum numbers of genera, with the lower variation when non-stratified sampling is used indicating a reduction in the capability to assess the variability that occurs from one soil layer to another. Further support for this hypothesis is provided by the fact that a smaller number of genera in the $0-30 \mathrm{~cm}$ layer is detected by comparison with the results of sampling each $10 \mathrm{~cm}$ layer individually, showing that non-stratified sampling does not give an accurate snapshot of ecosystem conditions. Richness is often an efficient measure for differentiating management systems (MATTOS et al., 2006; TOMAZINI et al., 2008), although diversity is a more complex parameter.

At greater soil depths, the differences tend to fall, as we observed in this study in the $0-30 \mathrm{~cm}$ layer, in which the similarity between the systems studied showed a tendency toward value approximation. This decrease in difference is to be expected because the differences in nematode abundances at lower depths are less marked (HOU et al., 2010) and can occur due to natural edaphic factors (OU et al., 2005), root development and distribution (PEN-MOURATOV et al., 2004), anthropogenic disturbances (YEATES; KING, 1997) and the time of year at which sampling was conducted (LIANG et al., 1999).

The formation of groups closely related to sampling depth shows that if sampling is continuous (non-stratified) across the profile, a great deal of important information can be lost, and problems may be encountered in differentiating between even widely differing management systems. Because tillage and the incorporation of plant residues can favor groups of nematodes with short life cycles and 
low c-p values, especially bacterial-feeding species (ETTEMA; BONGERS, 1993; LENZ; EISENBEIS, 2000), this is reflected in the low ecosystem stability at depths of $0-10 \mathrm{~cm}$, characteristic of succession communities (MANACHINI et al., 2009).

\section{Conclusions}

Stratified soil sampling provides a more accurate characterization and greater differentiation of nematode communities by identifying taxa with low abundance, irrespective of their frequency.

\section{Acknowledgements}

The authors thank the Brazilian National Scientific and Technological Development Council (CNPq), for their help in funding this project, and the National Soybean Research Center (EmbrapaSoja), for allowing us to use their experimental site.

\section{References}

ANDERSON, J. D.; INGRAM, J. S. I. Tropical soil biology and fertility: a handbook of methods. Wallingford: CAB International, 1993. $221 \mathrm{p}$.

ARAÚJO, A. S. F.; MONTEIRO, R. T. R. Indicadores biológicos de qualidade do solo. Bioscience Journal, Uberlândia, v. 23, n. 3, p. 66-75, 2007.

BLOEMERS, G. F.; HODDA, M.; LAMBSHEAD, P. J. D.; LAWTON, J. H.; WANLESS, F. R. The effects of forest disturbance on diversity of tropical soil nematodes. Oceologia, Aberdeen, v. 111, n. 4, p. 575-582, 1997.

BONGERS, T. De nematodden van Nederland. Amsterdam: Pirola Schoorl, 1987. 407 p.

BONGERS, T. The maturity index, the evolution of nematode life-history traits, adaptative radiation and cpscaling. Plant and Soil, The Hague, v. 212, n. 1, p. 13-22, 1999.

BONGERS, T.; FERRIS, H. Nematode community structure as a bioindicator in environmental monitoring. Trend in Ecology and Evolution, Cambridge, v. 14, n. 6, p. 224-228, 1999.

CARES, J. E.; HUANG, S. P. Comunidades de nematoides de solo sob diferentes sistemas na Amazônia e Cerrados brasileiros. In: MOREIRA, F. M. S.; SIQUEIRA, J. O.; BRUSSAARD, L. (Ed.). Biodiversidade do solo em ecossistemas brasileiros. Lavras: Editora UFLA, 2008. p. 409-444.

CURRY, J. P. Grassland invertebrates: ecology, influence of soil fertility and effects on plants growth. London: Chapman \& Hall, 1994. 451 p.

DE LEY, P.; BLAXTER, M. Systematic position and phylogeny. In: LEE, D. (Ed.). The biology of nematodes. London: Taylor \& Francis, 2002. p. 1-30.

ETTEMA, C. H.; BONGERS, T. X. Characterization of nematode colonization and succession in disturbed soil using the Maturity Index. Biology and Fertility of Soils, Berlin, v. 16, n. 2, p. 79-85, 1993.

FERRIS, H.; BONGERS, T.; DE GOEDE, R. G. M. Aframework for soil food web diagnostics: Extension of the nematode faunal analysis concept. Applied Soil Ecology, Amsterdam, v. 18, p. 13-29, 2001.

FORTUNER, R.; GERAERT, E.; LUC, M.; MAGGENTI, A. R.; RASKI, D. J. A. A reapprasial of Tylenchina (Nemata). Revue de Nématologie, Paris, v. 11, n. 2, p. 177-188, 1988.

FRECKMAN, D. W.; ETTEMA, C. H. Assessing nematode comunities in agroecossystems of varying human intervention. Agriculture, Ecosystem \& Environment, Amsterdam, v. 45, n. 3-4, p. 239-261, 1993.

FREITAS, L. G.; OLIVEIRA, R. D. L.; FERRAZ, S. Introdução à nematologia. Viçosa, MG: Editora UFV, 2001.84 p.

GOMES, G. S.; HUANG, S. P.; CARES, J. E. Nematode community, tropic structure and population fluctuation in soybean fields. Fitopatologia Brasileira, Brasília, v. 28, n. 3, p. 258-266, 2003.

GOSECO, C. G.; FERRIS, V. R.; FERRIS, J. M. Revision in Leptonchoidea (Nematoda: Dorylamida) Leptoconchus, Proleptonchus, Funaria and Meylis $n$. gen. West Lafayette: Purdue Nematode Collection, 1974a. 245 p.

Revision in Leptonchoidea (Nematoda: Dorylamida) Dorylaimoides in Dorylaimoididae, Calolaimus and Timmus $n$. gen. West Lafayette: Purdue Nematode Collection, 1974b. 276 p.

GOULART, A. M. C. Diversidade de nematoides em agroecossistemas e ecossistemas naturais. Planaltina: Embrapa Cerrados, 2007. 47 p.

GOULART, A. M. C.; FERRAZ, L. C. C. B. Comunidades de nematóides em Cerrado com vegetação original preservada ou substituída por culturas. 1. Diversidade 
trófica. Nematologia Brasileira, Piracicaba, v. 27, n. 2, p. 129-137, 2003.

HAIR, J. F.; TATHAM, R. L.; ANDERSON, R. E.; BLACK, W. Multivariate data analysis. Upper Saddle River: Prentice Hall, 1998. 827 p.

HOU, X.; HU, N.; ZHANG, X.; LIANG, L.; ZHAI, R. Vertical distribution of soil nematode communities under different tillage systems in Lower Reaches of Liaohe River. Chinese Geographical Sciences, Changchun, v. 20, n. 2, p. 106-111, 2010.

INSTITUTO BRASILEIRO DE GEOGRAFIA E ESTATÍSTICA - IBGE. Departamento de recursos naturais e estudos ambienais. Manual Técnico da Vegetação Brasileira. Rio de Janeiro: DEDIT/CDDI, 1992. $91 \mathrm{p}$.

JENKINS, W. R. A rapid centrifugal-floration technique for separating nematodes from soil. Plant Disease Reporter, Saint Paul, v. 48, n. 4, p. 692, 1964.

KORENKO, V.; SCHMIDT, C. Effects of agricultural pratices in the rice crop system on nematode communities in Uruguay. Nematologia Mediterranea, Bari, v. 34, n. 2, p. 133-140, 2006.

LENZ, R.; EISENBEIS, G. Short-term effects of different tillage in a sustainable farming system on nematode community structure. Biology and Fertility of Soils, New York, v. 31, n. 3-4, p. 237-244, 2000.

LIANG, W. J.; LAVIAN, I.; STEINBERGER, Y. Dynamics of nematode community composition in a potato field. Pedobiologia, Jena, v. 43, n. 5, p.459-469, 1999.

LIANG, W.; ZHANG, X.; JIANG, Q. L. I. Y.; OU, W.; NEHER, D. A. Vertical distribution of bacterivorous nematodes under different land uses. Journal of Nematology, Riverside, v. 37, n. 3, p. 254-258. 2005.

MANACHINI, B.; CORSINI, A.; BOCCHI, S. Soil quality indicators as affected by a long term barleymaize and maize cropping systems. Italian Journal of Agronomy, Roma, v. 4, n. 1, p. 15-22, 2009.

MATTOS, J. K. A.; HUANG, S. P.; PIMENTEL, C. M. R. M. Grupos tróficos da comunidade de nematoides do solo em oito sistemas de uso da terra nos Cerrados do Brasil Central. Nematologia Brasileira, Piracicaba, v. 30, n. 3, p. 267-273, 2006.

MENG, F.; OU, W.; LI, Q.; JIANG, Y.; WEN, D. Vertical distribution and seasonal fluctuation of nematode trophic groups as affected by land use. Pedosphere, New York, v. 16, n. 2, p. 69-176, 2006.
NEHER, D. A. Role of nematodes in soil health and their use as indicators. Journal of Nematology, Riverside, v. 33, n. 4, p. 61-168, 2001.

NEHER, D. A.; CAMPBELL, C. L. Nematode communities and microbial biomass insoil with annual and perennial crops. Applied Soil Ecology, Dublin, v. 1, n. 1, p. 17-28, 1994.

NORTON, D. C. Communities. In: (Ed.). Ecology of plant-parasitic nematodes. New York: John Wiley, 1978. p. 59-79.

NORTON, D. C.; NIBLACK, T. L. Biology and ecology of nematodes. In: NICKLE, W. R. (Ed.). Manual of agricultural nematology. New York: Marcel Dekker, 1991. p. 47-72.

OU, W.; LIANG, W. J.; JIANG, Y.; LI, Q.; WEN, D. Vertical distribution of soil nematodes under different land use types in an aquic brown soil. Pedobiologia, Jena, v. 49, n. 2, p. 139-148, 2005.

PEN-MOURATOV, S.; HE, X. L.; STEINBERGER, Y. Spatial distribution and trophic diversity of nematode populations under Acacia raddiana along a temperature gradient in the Negev Desert ecosystem. Journal of Arid Environments, New York, v. 56, n. 2, p. 339-355, 2004.

RODRIGUES, C. V. M. A.; PEDROSA, E. M. R.; OLIVEIRA, A. K. S.; LEITÃO, D. A. H. S.; BARBOSA, N. M. R.; OLIVEIRA, N. J. V. Distribuição vertical da nematofauna associada à cana-de-açúcar. Nematropica, Auburn, v. 41, n. 1, p. 5-11, 2011.

SANTIAGO, D. C.; ARIEIRA, G. O.; ALMEIDA, E.; GUIMARÃES, M. F. Responses of soil nematode communities to agroecological crop management systems. Nematology, Leiden, v. 14, n. 2, p. 209-221, 2012.

SMITH, R. L.; SMITH, T. M. Elements of ecology. San Francisco: Benjamin/Cummings Science Publishing, 1998. $655 \mathrm{p}$.

STEYAERT, M.; VANAVERBEKE, J.; VANREUSEL, A.; BARRANGUET, C.; LUCAS, C.; VINCX, M. The importance of fine-scale, vertical profiles in characterising nematode community structure. Estuarine, Coastal and Shelf Science, Hull, v. 58, n. 2, p. 353-366, 2003.

TOMAZINI, M. D.; FERRAZ, L. C. C. B.; MONTEIRO, A. R. Abundância e diversidade de nematoides em áreas contíguas de vegetação natural e submetida a diferentes tipos de uso agrícola. Nematologia Brasileira, Piracicaba, v. 32, n. 3, p. 185-193, 2008.

VALENTIN, J. L. Ecologia numérica: uma introdução à análise multivariada de dados ecológicos. Rio de Janeiro: Interciência, 2000. 117 p. 
YEATES, G. W. Populations of nematode genera in soils under pasture. III. vertical distribution at eleven sites. New Zealand Journal of Agricultural Research, Wellington, v. 23, n. 2, p. 117-128, 1980.

YEATES, G. W. Abundance, diversity, and resilience of nematode assemblage in forest soils. Canadian Journal of Forest Research, Ipswich, v. 37, n. 2, p. 216-225, 2007.
YEATES, G. W.; BONGERS, T.; DE GOEDE, R. G. M.; FRECKMAN, D. W.; GEORGIEVA, S. S. Feeding habits in nematodes families - an outline for soil ecologists. Journal of Nematology, Riverside, v. 25, n. 3, p. 315-331, 1993.

YEATES, G. W.; KING, K. L. Soil nematodes as indicators of the effect of management on grasslands in the New England Tablelands (NSW): comparison of native and improved grasslands. Pedobiologia, Jena, v. 41, n. 6, p. 526-536, 1997. 
